Ann. Biol. anim. Bioch. Biophys., 1978, 18 (2 B), 615-622.

\title{
Biochemical aspects of the interaction of androgens with Sertoli cells
}

\author{
by B. M. SANBORN, Y. H. TSAI, A. STEINBERGER, E. STEINBERGER \\ Department of Reproductive Medicine and Biology, \\ University of Texas Medical School at Houston, \\ Houston, Texas 77030, USA.
}

\begin{abstract}
Summary. Cultured rat Sertoli cells have been shown to contain the components of an androgen-responsive system. A macromolecule distinguishable from androgen binding protein and exhibiting a $\mathrm{K}_{\mathrm{d}}$ of $6.3 \mathrm{nM}$ for ${ }^{3} \mathrm{H}$-testosterone has been found in Sertoli cell cytosol. Effectiveness of unlabeled steroids in competing for ${ }^{3} \mathrm{H}$-testosterone binding sites was found to be testosterone $=$ dihydrotestosterone $>$ R1881 $>$ progesterone $=$ cyproterone acetate $>5 \alpha$-androstane- $3 \alpha, 17 \beta$-diol $>$ androsterone $>$ estradiol. After labeling the cells in culture with ${ }^{3} \mathrm{H}$-testosterone, macromolecular bound steroid could be extracted from the nuclear fraction with $0.4 \mathrm{M} \mathrm{KCl}$ and chromatographed on Sephadex G-200. Rechromatography of the bound fraction revealed negligible dissociation of the complex. Specific binding to the nuclear fraction was saturable with an apparent $K d$ of $2.2 \mathrm{nM}$. Chromatin prepared from Sertoli cell nuclei bound 3-4 times as much cytoplasmic androgen-receptor complex as did thymus or liver chromatin. The binding was optimal at $0.1 \mathrm{M}$ $\mathrm{NaCl}$ and exhibited two binding components when the assay was performed in the presence of a constant total protein concentration. The high affinity component exhibited a $K_{d}$ of $8 \mathrm{pM}$ and 6 fmoles of sites/mg DNA. These data indicate that the Sertoli cell has the capacity to respond to androgens in a manner similar to that described for other steroid target cells.
\end{abstract}

\section{Introduction.}

The recent expansion of biochemical knowledge concerning hormone action in the testis has supported the concept that the Sertoli cell mediates hormonal effects on spermatogenesis (see Steinberger E. (1975), Steinberger E. ef al. (1977) and Hansson ef al. (1975) for reviews). Thus Sertoli cells bind FSH and respond to this hormone with elevated CAMP levels and secretion of an androphilic protein called androgen binding protein or ABP (Steinberger E. et al., 1977). That the Sertoli cell can also respond to androgen (and hence indirectly to $L H$ ) was suggested by the fact that under certain circumstances production of $\mathrm{ABP}$ can also be regulated by androgens (Elkington et al., 1975 ; Means ef al., 1976 ; Louis and Fritz, 1977). Furthermore, testicular androgen receptor-like macromolecules which persisted following hypophysectomy and germ cell depletion have been described (Hansson et al., 1974 ; Mulder et al., 1974).

This presentation summarizes our evidence that Sertoli cells are target cells 
for androgen action. We show that macromolecules with the properties of androgen receptors can be found in the cytoplasmic fraction from cultured Sertoli cells prior to incubation with steroid and in the nuclear fraction after incubation with steroid. We also show that cultured Sertoli cells contain chromatin acceptor sites for androgenreceptor complexes.

\section{Materials and methods.}

Preparation of androgen receptor. - Sertoli cells were isolated from 28-30 d animals and cultured for 2-3 $d$ as described by Steinberger A. ef al. (1975). The cytoplasmic form of the receptor was prepared as described elsewhere except that the precipitate obtained at 40 p. 100 saturation with $\left(\mathrm{NH}_{4}\right)_{2} \mathrm{SO}_{4}$ was collected, redissolved and desalted on a Sephadex G-25 column (Sanborn ef al., 1977). The void volume eluted from this column was used as cytoplasmic receptor. Androgen-receptor complex for use in the chromatin acceptor assay was prepared from the testes of 14-21 d hypophysectomized rats $60 \mathrm{~d}$ of age of surgery by a similar procedure (Tsai et al., 1977).

To obtain the nuclear form of the receptor, cells were washed and then incubated with ${ }^{3} \mathrm{H}$-testosterone $\left(1,2,6,7,{ }^{-3} \mathrm{H}, 85 \mathrm{Ci} / \mathrm{mmole}\right.$, New England Nuclear) for $30 \mathrm{~min}$ at $37 \mathrm{o}$, and then treated by a procedure involving homogenization, centrifugation and subsequent washing of the pellets once with 0.3 p. 100 Triton X-100 and twice with buffer (Sanborn ef al., 1977). The pellets were extracted with $0.4 \mathrm{M} \mathrm{KCl}, 1 \mathrm{mM}$ EDTA, $0.01 \mathrm{M}$ Tris $\mathrm{HCl} \mathrm{pH} 7.4$ and/or ether. The resulting pellets were used to determine DNA and extracts were counted as described elsewhere (Sanborn et al., 1977).

Chromatin acceptor assay. - Nuclei from thymus and liver of 30-31 d old rats were isolated by procedures described by Tsai et al. (1977). Sertoli cell nuclei were obtained from cultured cells by lysing the cells in $5 \mathrm{mM} \mathrm{MgCl}$, collecting the nuclei by centrifugation through $0.25 \mathrm{M}$ sucrose, washing the nuclei with $0.3 \mathrm{p}$. 100 Triton $\mathrm{X}-100$ and purifying the nuclei by centrifugation through a discontinuous gradient composed of 2.2, 1.8, and 1.6 M sucrose in buffer (Tsai et al., 1977). Chromatin was prepared as described elsewhere (Tsai ef al., 1977), using $0.08 \mathrm{M} \mathrm{NaCl}-0.02 \mathrm{M}$ EDTA $\mathrm{pH} 6.4$ to lyse the nuclei and washes of $0.3 \mathrm{M} \mathrm{NaCl}$ and $1.5 \mathrm{mM} \mathrm{NaCl}-0.15 \mathrm{mM} \mathrm{Na}$ citrate $\mathrm{pH}$ 7.0. Sertoli cell chromatin preparations were subjected to an additional centrifugation through $1.7 \mathrm{M}$ sucrose.

Initial studies involved incubation of chromatin preparations (100-200 $\mu \mathrm{g}$ DNA) with ${ }^{3} \mathrm{H}$-testosterone-receptor complex at $26^{\circ} \mathrm{C}$ for $1 \mathrm{hr}$ in $0.15 \mathrm{M} \mathrm{NaCl}, 0.5 \mathrm{mM}$ EDTA, $5 \mathrm{mM}$ Tris $\mathrm{HCl} \mathrm{pH} \mathrm{7.4.} \mathrm{More} \mathrm{recent} \mathrm{studies} \mathrm{employed} \mathrm{optimized} \mathrm{incubation} \mathrm{conditions}$ (see figure legends). After the desired interval, cold $0.15 \mathrm{M} \mathrm{NaCl}-10 \mathrm{mM} \mathrm{MgCl} 2$ was added and the suspensions were centrifuged $(15000 \times \mathrm{g}, 20 \mathrm{~min})$. The precipitated chromatin was washed twice by a similar procedure and the radioactivity was extracted with ether, evaporated, and counted (Tsai ef al., 1977).

\section{Results and discussion.}

The cytoplasmic form of the androgen receptor. - Cytosol fractions from cultured Sertoli cells were labeled with ${ }^{3} \mathrm{H}$-testosterone either prior to the ultracentrifugation 
step or subsequent to chromatography, depending on the purpose intended. Yields using either procedure were approximately equivalent, indicating the relative stability of the receptor during the separation procedures. The androgen-receptor complex was clearly distinguishable from ABP by electrophoresis on 0.5 p. 100 agarose/3.3 p. 100 polyacrylamide gels (Sanborn et al., 1977). ABP exhibited an Rf of 0.79 while the receptor complex exhibited an $\mathrm{Rf}$ of 0.43 . This behavior is consistent with the behavior of receptor complexes isolated from whole testes (Hansson ef al., 1974). Furthermore, incubation of the labeled complexes with excess unlabeled steroid for $30 \mathrm{~min}$ at $0{ }^{\circ} \mathrm{C}$ prior to electrophoresis abolished binding in the ABP area but did not affect that in the receptor area, consistent with the shorter $t_{2} \frac{1}{2}$ of dissociation of the ABP complex (Sanborn et al., 1975).

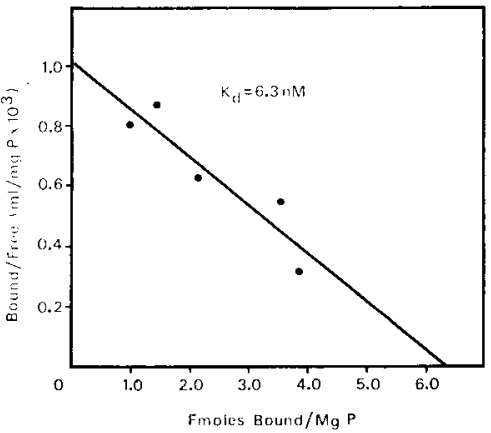

FIG. 1. - Scatchard plot of the specific binding of ${ }^{3} \mathrm{H}$-testosterone to cytosol prepared from cultured Sertoli cells. Aliquots of cytosol were incubated with 0.5-9 $\mathrm{nM}{ }^{3} \mathrm{H}$-testosterone or labeled steroid plus 100 -fold molar excess of unlabeled steroid at $0^{\circ}$ for $18 \mathrm{hr}$. Samples were applied to $0.5 \times 7 \mathrm{~cm}$ Sephadex G-25 columns, aliquots were collected and counted, and the counts eluting in the void volume were calculated. Specific binding was considered to be the difference between binding of the labeled steroid in the absence and in the presence of unlabeled steroid.

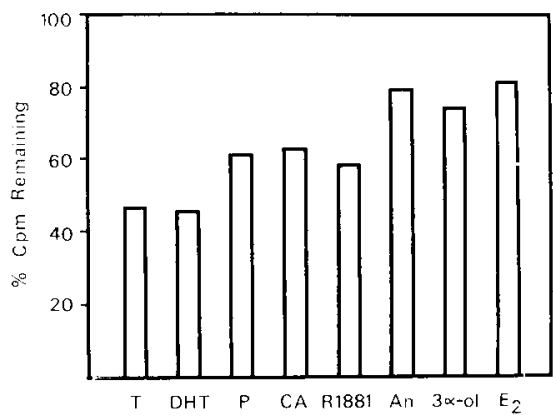

FIG. 2. - The ability of 100 -fold molar excess of unlabeled steroids to compete with ${ }^{3} \mathrm{H}$-festosterone for binding sites in Sertoli cell cytosol. ${ }^{3} \mathrm{H}$-festosterone $(9 \mathrm{nM})$ and unlabeled steroids were mixed prior to the addition of cytosol. After $18 \mathrm{hr}$ at $0^{\circ}$, bound steroid was estimated as described for Figure 1. T : testosterone, DHT : $17 \beta$-hydroxy-5 $\alpha$-androstan-3-one ; $\mathrm{P}$ : progesterone ; CA : 1, $2 \alpha$-methylene-6-chloro-4,6-pregnadien-17 $\alpha$-0l-3, 20-dione-17-acetate ; RI881 : $17 \beta$-hydroxy-17 $\alpha$-methylestra-4, 9, 11 -trien-3-one ; An : $3 \alpha$-hydroxy- $5 \alpha$-androstan-17-one ; $3 \alpha$-ol : $5 \alpha$-androstane-3 $\alpha$, $17 \beta$-diol ; $E_{2}: 17 \beta$-estradiol. 
Figure 1 shows that binding of androgen to the cytosol fraction from Sertoli cells was saturable with $a K_{d}$ in the $n M$ range. The concentration of binding sites was usually in the range of $10 \mathrm{fmoles} / \mathrm{mg}$ protein. The binding sites showed specificity for androgens, with the greatest competition exhibited by testosterone and dihydrotestosterone, but progesterone also competed with ${ }^{3} \mathrm{H}$-testosterone for binding sites (fig. 2 ). This order of specificity is similar to that reported elsewhere for binding at the nuclear sites in Sertoli cells (Sanborn et al., 1977). The interaction of progestogens with androgen receptors in other target tissues has been described at some length by Bardin et al. (1975).

The nuclear form of the androgen receptor. - Accumulation of label into the nuclear fraction from cultured Sertoli cells was temperature-and time-dependent (Sanborn et al., 1977). Binding was also saturable with an apparent $K_{d}$ of $2.2 \mathrm{nM}$ for both $0.4 \mathrm{M}$ $\mathrm{KCl}$ extractable and total specific binding with 0.14 and 0.30 pmoles of binding sites/ mg DNA, respectively (Sanborn et al., 1977). In general, about 30 p. 100 of the radioactivity was extractable with $0.4 \mathrm{M} \mathrm{KCl}$ in $1 \mathrm{hr}$; larger amounts could be extracted by incubation for an additional $16 \mathrm{hr}$. The material extracted with $0.4 \mathrm{M} \mathrm{KCl}$ eluted from a Sephadex-200 column in the void volume ( $\sim 33$ p. 100) and as unbound steroid (67 p. 100) (fig. 3). The proportion of label in the bound fraction could be increased by prior extraction of the nuclei with $0.1 \mathrm{M} \mathrm{KCl}$, but the total amount of bound label remained essentially constant (data not shown). Rechromatography of the material eluting in the void volume did not result in further dissociation of the complex (fig. 3 ).

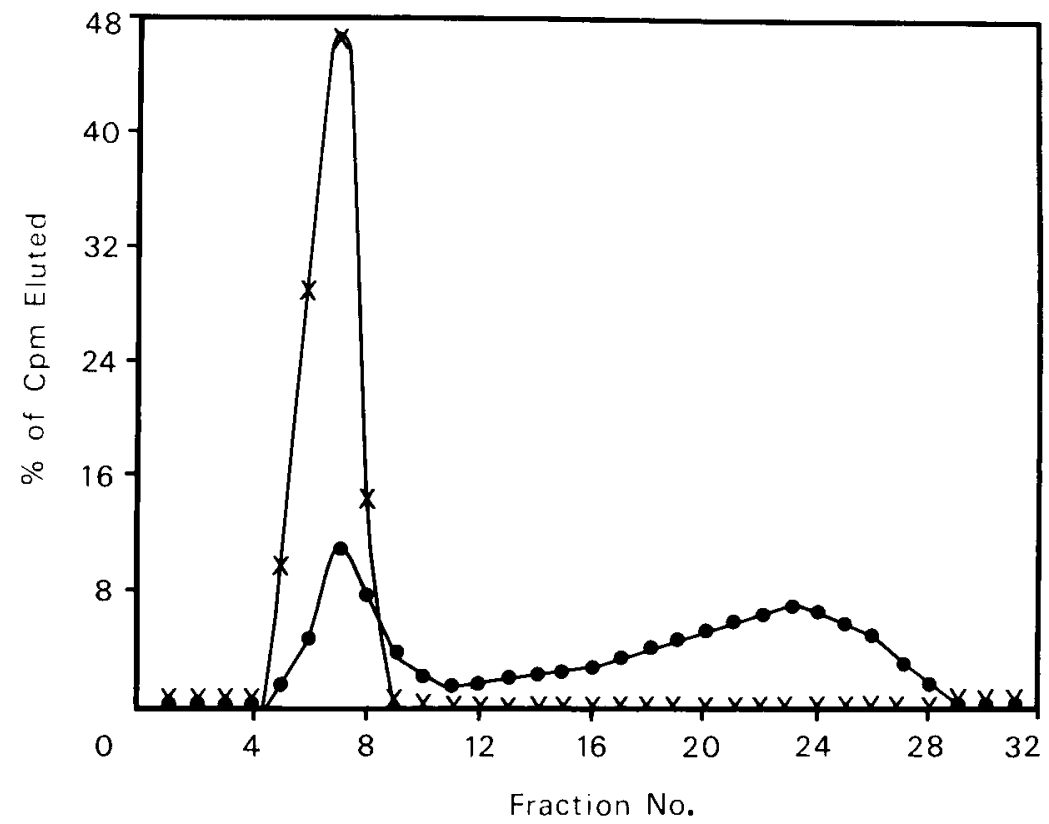

FIG. 3. - The elution pattern on Sephadex G-200 of a $0.4 \mathrm{M} \mathrm{KCl}$ extract $\left(1 \mathrm{hr}, 4{ }^{\circ} \mathrm{C}\right)$ of the Sertoli cell nuclear pellet after exposure of the cells to ${ }^{3} \mathrm{H}$-testosterone. $\bullet-\bullet$, initial extract; $\mathrm{X}-\mathrm{X}$, an aliquot from the void volume (fractions 5-8) rechromatographed on the same column after standing $4 \mathrm{hr}$ at $0^{\circ} \mathrm{C}$. 
Chromatin acceptor sites for androgen-receptor complexes. - Chromatin acceptor sites for androgen-receptor complexes have been found in preparations from rat testis by Klyzsejko-Stefanowicz et al. (1976) but the cell types involved were not delineated. While attempting to purify Sertoli cell nuclei in preparation for chromatin isolation, we noted that the nuclei obtained from cultured cells did not sediment through 2.2 $\mathrm{M}$ sucrose. The Sertoli cell nuclei sedimented at the 1.6-1.8 $\mathrm{M}$ and 1.8-2.2 $\mathrm{M}$ sucrose interfaces of a discontinuous sucrose gradient while the residual germ cell nuclei sedimented through $2.2 \mathrm{M}$ sucrose at $120000 \times \mathrm{g}$. The use of Sertoli cells from 2 day cultures combined with this gradient separation yielded a preparation containing 95 p. 100 recognizable Sertoli cell nuclei (Tsai ef al., 1977). The chromatin preparations isolated from purified nuclei of rat liver, thymus and cultured Sertoli cells exhibited acid-soluble protein/DNA ratios of 1.0, 0.98 and 1.2, respectively. Using a fixed amount of labeled receptor complex with $200 \mu \mathrm{g}$ chromatin DNA, Sertoli cell chromatin bound 3-4 times as much ${ }^{3} \mathrm{H}-\mathrm{T}$ receptor complex as did the chromatin from thymus or liver (Tsai ef al., 1977). Using a fixed amount of chromatin and increasing amounts of labeled cytosol complex, a biphasic Scatchard plot of binding was observed at $0.15 \mathrm{M} \mathrm{NaCl}, 26^{\circ} \mathrm{C}$. Subsequent experiments showed the optimal temperature and time for incubation to be $15^{\circ} \mathrm{C}$ for $1 \mathrm{hr}$ (Tsai et al., manuscript in preparation). Figure 4 shows that the optimal salt concentration using androgen-receptor complex which had been precipitated with $\left(\mathrm{NH}_{4}\right)_{2} \mathrm{SO}_{4}$ was $0.1 \mathrm{M} \mathrm{NaCl}$.

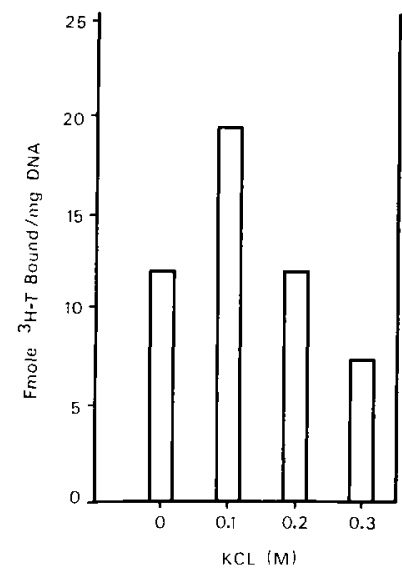

FIG. 4. - Variation in the amount of ${ }^{3} \mathrm{H}$-testosterone-androgen receptor complex bound to Sertoli cell chromatin $\left(200 \mu \mathrm{g}\right.$ DNA) after incubating for $1 \mathrm{hr}$ at $15^{\circ} \mathrm{C}$ in the presence of the $\mathrm{NaCl}$ concentration indicated, $0.5 \mathrm{mM}$ EDTA and $5 \mathrm{mM}$ Tris- $\mathrm{HCl} \mathrm{pH}$ 7.4. Bound complex was estimated as described in Methods.

A binding analysis was subsequently performed on data obtained after incubation of receptor complex with a fixed amount of Sertoli cell chromatin. Total protein concentration was kept constant by addition of heat-inactivated cytosol processed in a manner identical to that used for the fractionation of the receptor complex. Figure 5 shows that under these conditions, the Scatchard plot was still biphasic. Resolution of the binding components yielded a $\mathrm{K}_{\mathrm{d}}$ of $\sim 8 \mathrm{pM}$ for the high affinity component 
with 6 fmoles of binding sites/mg DNA. These data indicate that binding sites of limited capacity and high affinity are present in the chromatin obtained from cultured Sertoli cells.

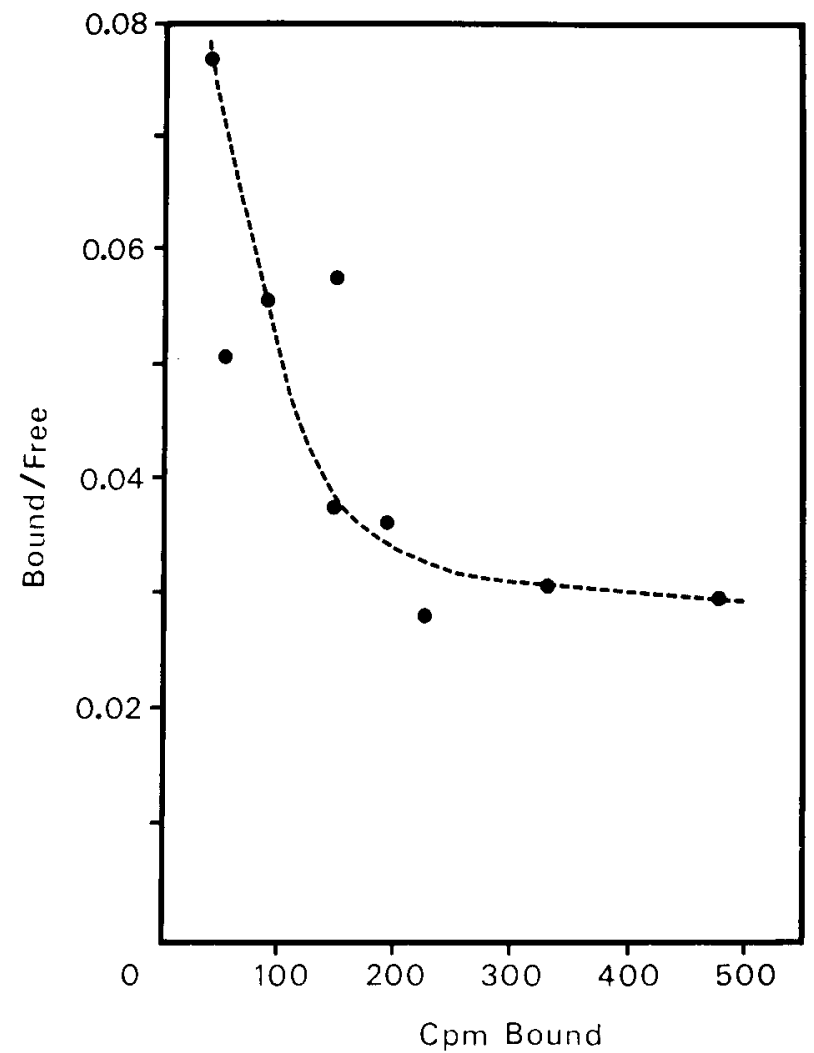

FIG. 5. - Scatchard analysis of the binding of ${ }^{3} \mathrm{H}$-testosterone-androgen receptor complex (3-195 $\left.\mathrm{pM}\right)$ to Serfoli cell chromatin $(100 \mu \mathrm{g} \mathrm{DNA})$ after incubation at $15^{\circ} \mathrm{C}$ for $1 \mathrm{hr}$ in the presence of $0.10 \mathrm{M} \mathrm{NaCl}$. The total protein concentration was kept at $4.5 \mathrm{mgP} / \mathrm{ml}$ by the addition of heat -inactived cytosol concentrated in a manner identical to that used for active cytosol. The specific activity of ${ }^{3} \mathrm{H}$-testosterone was $8.5 \times 10^{4} \mathrm{cpm} / \mathrm{pmole}$.

\section{Conclusions.}

The Sertoli cell has been demonstrated to have the capacity to respond to androgen in a manner similar to that described for other steroid hormone target tissues. (Baulieu, et al., 1975 ; Buller and O'Malley, 1976). It possesses a cytoplasmic form of androgen receptor which is distinguishable from ABP. After incubation of cells with labeled hormones, a nuclear form of receptor can be isolated. Finally, the chromatin from cultured Sertoli cells possesses a limited number of high affinity acceptor sites for cytoplasmic androgen-receptor complex. In vivo (Elkington et al., 1975 ; Means et al., 1976) and in vitro (Lovis et al., 1977) evidence suggests that the production of 
ABP by Sertoli cells is regulated in part by androgens. Together these data provide strong evidence that Sertoli cells are primary target cells for androgen action in the testis.

$27^{e}$ Congrès international des Sciences physiologiques, Symposium "Germ and somatic cell interaction 》 Paris, 21-23 juillef 1977.

Acknowledgements. - The authors acknowledge the capable technical assistance of H. S. Kuo, S. Green, M. Rabon, C. Williamson and S. H. Su in this work. This work was supported by NIH-5-P50-HDO8338. BMS is the recipient of NIH Research Career Development Award \# 1-KO4-HDOO126.

Résumé. Les cellules de Sertoli de rat en culture contiennent les éléments d'un système sensible aux androgènes. Le cytosol des cellules de Sertoli contient une macromolécule différente de l'ABP et présentant un $\mathrm{K}_{\mathrm{d}}$ de $6,3 \mathrm{nM}$ pour la ${ }^{3} \mathrm{H}$-testostérone. L'efficacité compétitive des stéroïdes froids sur les sites de liaison avec la ${ }^{3} \mathrm{H}$-testostérone est dans l'ordre : testostérone $=$ dihydrotestostérone $>$ R1881 $>$ progestérone $=$ acétate de cyprotérone $>5 \alpha$-androstane- $3 \alpha, 17 \beta$-diol $>$ androstérone $>$ estradiol. Après marquage des cellules en culture par la ${ }^{3} \mathrm{H}$-testostérone, le stéroïde lié à la macromolécule peut être extrait de la fraction nucléaire par du $\mathrm{KCl} 0,4 \mathrm{M}$ et une chromatographie sur Séphadex G. 200. Une seconde chromatographie de la fraction liée n'entraîne qu'une dissociation négligeable du complexe. La liaison spécifique à la fraction nucléaire est saturable, avec un $K_{d}$ apparent de 2,2 $\mathrm{nM}$. La chromatine préparée à partir des noyaux des cellules de Sertoli a un pouvoir de liaison avec le complexe cytoplasmique liant. les androgènes 3 à 4 fois supérieur à la chromatine du foie ou du thymus. La liaison est optimale dans du $\mathrm{NaCl} 0,1 \mathrm{M}$ et on met en évidence deux composants quand l'expérience est réalisée en présence d'une concentration protéique totale constante. Le composant à forte affinité se définit par un $K_{d}$ de $8 \mathrm{pM}$ et une concentration de 6 fmoles de sites/mg ADN. Ces résultats montrent que la cellule de Sertoli a la capacité de répondre aux androgènes de la même manière que celle décrite pour les autres cellules cibles des stéroïdes.

\section{References}

BARDIN C. W., JANNE O., BULLOCK L. P., JACOB S. T., 1975. Physiochemical and biological properties of androgen receptors, 237-255. In FRENCH F. S., HANSSON V., RITZÉN E. M. and NAYFEH S. N., Hormonal regulation of spermatogenesis, Plenum Press, New York.

BAULIEU E. E., ATGER M., Best-BelPOMME M., CORVAL P., COURVALIN J. C., MESTER J., MILGROM E., ROBEL P., ROCHEFORT H., de CATALOGNE D., 1975. Steroid hormone receptors. Vitam. Horm., 33, 649-736.

BULLER R. E., O'MALLEY, B. W., 1976. The biology and mechanism of steroid hormone receptor interaction with the eukaryotic nucleus. Biochem. Pharmocol., 26, 1-12.

ELKINGTON J. S. H., SANBORN B. M., STEINBERGER E., 1975. The effect of testosterone propio. nate on the concentration of testicular and epididymal androgen binding action in the hypophysectomized rat. Molec. Cell. Endocrinol., 2, 157-170.

HANSSON V., MCLEAN W. S., SMITH A. A., TINDALL D. J., WEDDINGTON S. C., NAYFEH S. N., FRENCH F. S., 1974. Androgen receptors in rat testes. Steroids, 23, 823-832.

HANSSON V., RITZEN E. M., FRENCH F. S., NAYFEH S. H., 1975. Androgen transport and receptor mechanism in testis and epididymis, 173-201. In HAMILTON D. W., GREEP R. O., Handbook of Physiology, Amer. Physiol. Soc. Washington, D. C.

KLYZSEJKO-STEFANOWICZ L., CHIU J. F., TSAI Y. H., HNILICA L., 1976. Receptor proteins in rat androgenic tissue chromatin. Proc. nat. Acad. Sci. USA, 73, 1954-1958. 
LOUIS B. G., FRITZ I. B., 1977. Stimulation by androgens of the production of androgen binding protein by cultured Sertoli cells. Molec. Cell. Endocrinol., 7, 9-16.

MEANS A. R., FAKUNDING J. L., HUCKINS C., TINDALL D. J., VITALE R., 1976. Follicle stimulafing hormone, the Sertoli cell, and spermatogenesis. Recent Prog. Horm. Res., 32, 477-522.

MULDER E., PETERS M. J., VAN BEURDEN W. M. O., VAN DER MOLEN H. J., 1974. A receptor for testosterone in mature rat testis. FEBS Letters, 47, 209-211.

SANBORN B. M., ELKINGTON J. S. H., TCHOLAKIAN R. K., STEINBERGER E., 1975. Some properties of androgen binding activity in rat testis. Molec. Cell. Endocrinol., 3, 129-142.

SANBORN B. M., STEINBERGER A., TCHOLAKIAN R. K., STEINBERGER E., 1977. Direct measurement of androgen receptors in cultured Sertoli cells. Steroids, 29, 493-502.

STEINBERGER A., HEINDEL J. J., LINDSEY J. N., ELKINGTON J. S. H., SANBORN B. M., STEINBERGER E., 1975. Isolation and culture of FSH responsive Sertoli cells. Endocr. Res. Comm., 2, 261-272.

STEINBERGER E., 1975. Hormonal regulation of the seminiferous fubule function, 337-352. In FRENCH F. S., HANSSON V., RITZEN E. M., NAYFEH S. N., Hormanal regulation of spermatogenesis, Plenum Press, New York.

STEINBERGER E., STEINBERGER A., SANBORN B. M., 1977. Molecular mechanisms concerned with hormonal control of the seminiferous epithelium. In FABBRINI A., STEINBERGER E., Recent progress in andrology, Serono Symp., Acad. Press (in press).

TSAI Y. H., SANBORN B. M., STEINBERGER A., STEINBERGER E., 1977. The interaction of testicular androgen-receptor complex with rat germ cell and Sertoli cell chromatin. Biochem. Biophys. Res. Comm., 75, 366-372. 